Zeszyty Naukowe Szkoły Głównej Gospodarstwa Wiejskiego w Warszawie

Problemy Rolnictwa Światowego tom 18 (XXXIII), zeszyt 4, 2018: 222-235

DOI: 10.22630/PRS.2018.18.4.113

Elżbieta M. Kacperska ${ }^{1}$

Szkoła Główna Gospodarstwa Wiejskiego w Warszawie

\title{
Działalność podmiotów z kapitałem zagranicznym w polskim rolnictwie
}

\section{Economic Activity of Entities with Foreign Capital in Polish Agriculture}

\begin{abstract}
Synopsis. W 2015 roku w polskim rolnictwie działało 690 podmiotów z kapitałem zagranicznym, zatrudniając ponad 5,7 tys. osób. Kapitał zagraniczny zainwestowany w tych podmiotach stanowił ponad 90\% udziału kapitału podstawowego. Celem opracowania było określenie skali działalności podmiotów z kapitałem zagranicznym w polskim rolnictwie. Analiza obejmowała liczbę podmiotów, rozmieszczenie geograficzne, liczbę zatrudnionych, obroty handlowe z zagranicą i wyniki finansowe.

Słowa kluczowe: inwestycje zagraniczne, rolnictwo, agrobiznes, zatrudnienie, eksport, wyniki finansowe

Abstract. In 2015, there were 690 entities with foreign capital operating in Polish agriculture, employing over 5.7 thousand. people. The foreign capital invested in these entities accounted for over $90 \%$ of the share of the share capital. The purpose of the article was to determine the scale of operations of entities with foreign investments in Polish agriculture. The analysis included the number of entities, geographical distribution, number of employees, foreign trade turnover and financial results.
\end{abstract}

Key words: foreign investments, agriculture, agribusiness, employment, export, financial results

JEL Classification: F21, O13, Q13

\section{Wprowadzenie}

Przepływy kapitału zagranicznego w skali międzynarodowej są zjawiskiem powszechnym. W XXI wieku inwestycje zagraniczne należą do najbardziej dynamicznych strumieni międzynarodowych przepływów gospodarczych obok towarów i usług. Proces globalizacji powoduje przemieszczanie się nie tylko towarów ale również zakładów produkcyjnych, które pod postacią bezpośrednich inwestycji zagranicznych są lokowane w różnych częściach świata. Bezpośrednie inwestycje zagraniczne są definiowane jako międzynarodowe przepływy kapitału polegające na lokowaniu go $\mathrm{w}$ przedsiębiorstwie innego kraju w celu uzyskania trwałego wpływu na jego działalność i osiaganiu z tego tytułu zysków (Kacperska, 2000). Głównymi kreatorami światowych przepływów są kraje rozwinięte, posiadające kapitał. Kapitał ten najcześsciej jest lokowany $\mathrm{w}$ atrakcyjnych branżach min: $\mathrm{w}$ handlu, $\mathrm{w}$ przetwórstwie przemysłowym, IT, budownictwie. Jednym z kierunków napływu inwestycji jest też rolnictwo i agrobiznes.

\footnotetext{
${ }^{1}$ dr inż., Katedra Ekonomiki Rolnictwa i Międzynarodowych Stosunków Gospodarczych, SGGW, ul. Nowoursynowska 162,02-787 Warszawa, e-mail: elzbieta_kacperska@sggw.pl https://orcid.org/0000-0002-6810-7037
} 
Od początku obecnego stulecia obserwujemy dynamiczny napływ inwestycji zagranicznych do Polski. W 2015 r. w Polsce zainwestowało około 26 tys. podmiotów $\mathrm{z}$ kapitałem zagranicznym, $\mathrm{w}$ tym ponad 2 tys. $\mathrm{w}$ rolnictwie, przemyśle rolno-spożywczym i otoczeniu rolnictwa.

Celem opracowania było określenie skali działalności podmiotów z kapitałem zagranicznym w polskim rolnictwie i próba oceny ich działalności. Analiza obejmuje podmioty z kapitałem zagranicznym działające w grupach od 011 do 016 działu 01 , sekcji A Polskiej Klasyfikacji Działalności Gospodarczej z 2007 roku (PKD 2007). Sekcja A PKD 2007 obejmuje rolnictwo, leśnictwo, łowiectwo i rybactwo. Jednak analiza dotyczyła tylko rolnictwa obejmującego: (01.1) uprawy rolne, (01.2) rośliny wieloletnie, (01.3) rozmnażanie roślin, (01.4) chów i hodowlę zwierząt, (01.5) działalność mieszaną oraz (01.6) działalność usługową. Do realizacji celów badawczych wykorzystano dane dotyczące działalności podmiotów z kapitałem zagranicznym w rolnictwie pochodzące z niepublikowanych materiałów Głównego Urzędu Statystycznego za lata 2009 -2015. Źródłem danych wykorzystanych przez GUS były roczne sprawozdania statystyczne podmiotów z udziałem kapitału zagranicznego oraz roczne ankiety przedsiębiorstw. Zakres przedmiotowy analizy obejmował wielkość i strukturę kapitału zaangażowanego w rolnictwie, liczbę zatrudnionych, obroty w handlu zagranicznym oraz wyniki prowadzonej działalności (przychody, koszty, wyniki finansowe brutto itp.). Analizowane dane odnoszące się do liczby podmiotów, zatrudnienia, handlu zagranicznego, kapitału podstawowego i zagranicznego obejmowały wszystkie podmioty, natomiast dane dotyczace kapitału własnego i analizy wskaźnikowej obejmowały tylko podmioty o liczbie pracujących $10 \mathrm{i}$ więcej osób. Ze względu na tajemnicę statystyczną, niektóre dane nie były udostępnione przez GUS, co ograniczało analizę. Niepełne dane były powodem ograniczonej analizy dla niektórych grup działalności rolniczej.

W opracowaniu wykorzystano analizę opisową i porównawczą. Dane dotyczące podmiotów z kapitałem zagranicznym odnoszono do sektora agrobiznesu obejmującego działalność podmiotów z kapitałem zagranicznym w rolnictwie i jego otoczeniu (wybrane grupy z sekcji A, G, I).

\section{Bezpośrednie inwestycje zagraniczne - przegląd literatury}

Podmioty z kapitałem zagranicznym w literaturze przedmiotu są określane jako korporacje, które w procesie umiędzynarodowienia działalności gospodarczej rozpoczynają działalność poza granicami kraju. Przedsiębiorstwa te określane są korporacjami transnarodowymi (KTN) (tj.: przedsiębiorstwami działającymi $\mathrm{w}$ formie spółek kapitałowych (akcyjnych lub z.o.o)) a ich struktura organizacyjna składa się z jednostki macierzystej oraz licznych fili, które pod postacią min. bezpośrednich inwestycji zagranicznych są lokowanie za granicą kraju (UNCTAD, 2005; Chechelski, 2008; Kacperska, 2016). Bezpośrednie inwestycje zagraniczne mogą napływać w formie inwestycji od podstaw (greenfield) tj.: inwestycji, gdzie powstaje nowa filia za granica, inwestycji tworzonych poprzez zakup udziałów w już istniejących firmach zagranicznych (brownfield), w formie joint venture, czyli bliskiej współpracy dwóch lub więcej podmiotów z różnych krajów, oraz poprzez nabycie majątku nieruchomego za granicą w celu rozszerzenia dotychczasowej działalności (Kacperska, 2016). 


\section{E.M. Kacperska}

Jodkowski wskazuje, że pod względem struktury własności występują trzy rodzaje zagranicznych inwestycji bezpośrednich: całkowicie opanowane filie zagraniczne, (95\% lub więcej kapitału zakładowego jest własnością firmy macierzystej); udziały większościowe (50\% do 95\% kapitału zakładowego jest własnością firmy macierzystej); udziały mniejszościowe (poniżej 50\%) (Jodkowski, 1995).

W literaturze przedmiotu można spotkać wiele klasyfikacji związanych z motywami przepływu kapitału. Najczęściej wskazywane są motywy rynkowe, zasobowe, efektywnościowe i strategiczne (Zorska, 2002; Kraciuk, 2004). „W Polsce działalność korporacji jest umotywowana głównie dążeniem do wykorzystania rynku zbytu, podstawowych zasobów i tradycyjnych zdolności wytwórczych" (Kraciuk, 2004). Inwestorzy zagraniczni podejmując decyzję o lokalizacji inwestycji w polskim agrobiznesie najczęściej wskazują: wielkość rynku zbytu, niskie koszty siły roboczej, podaż siły roboczej, kwalifikacje siły roboczej, pozyskanie zasobów, obniżenie kosztów, niskie podatki, perspektywy wzrostu gospodarczego, członkostwo w UE, korzystne położenie w Europie, możliwość eksportu do innych krajów, dostępność do lokalnych surowców (Chechelski, 2008; Kacperska, 2000).

$\mathrm{Z}$ analizy literatury wynika, że bezpośrednie inwestycje zagraniczne wpływają na gospodarkę kraju goszczącego zarówno pozytywne jak i negatywne. Gorynia wskazuje na sześć efektów zewnętrznych inwestycji zagranicznych, tj.: efekty ogólnogospodarcze, polityczne, społeczne, obroty gospodarcze, naukę i technikę i konkurencyjność przedsiębiorstw (Gorynia, 2005; Chechelski, 2008). Wśród pozytywnych aspektów inwestycje wymieniane są jako czynnik: ożywiający i unowocześniający gospodarkę, czynnik poprawy efektywności gospodarowania, uzupełnienie krajowych funduszy inwestycyjnych, polepszenie zaopatrzenia, czynnik zwiększenia zdolności eksportowych, tworzenia nowych miejsc pracy, wdrażania nowości technicznych i technologicznych, poprawę jakości produktów. Do negatywnych efektów zaliczamy min: ograniczenie suwerenności krajowej polityki, wzrost importu, ryzyko napływu brudnych technologii, ryzyko nieuczciwej konkurencji, redukcję zatrudnienia (Kacperska, 2016; Chechelski, 2008)

Większość badań dotyczących bezpośrednich inwestycji zagranicznych w Polsce dotyczy klimatu inwestycyjnego, determinant napływu, wpływu inwestycji na rozwój regionalny. Zdecydowana większość opracowań dotyczy działalności przemysłowej. Problematyka napływu inwestycji zagranicznych do sektora agrobiznesu jest bardzo rzadko poruszana.

\section{Wyniki badań}

\section{Podmioty z kapitałem zagranicznym w Polsce}

Liczba podmiotów z kapitałem zagranicznym inwestujących w Polsce od 2009 r. charakteryzowała się tendencją wzrostową. Do 2014 r. liczba podmiotów z kapitałem zagranicznym zwiększyła się o prawie 5 tys. Jednak w ostatnich latach spada liczba rejestrowanych podmiotów. W 2016 r. odnotowano 24,7 tys. podmiotów z kapitałem zagranicznym wobec 26,4 tys. w 2014 r. (Kacperska, 2018). 


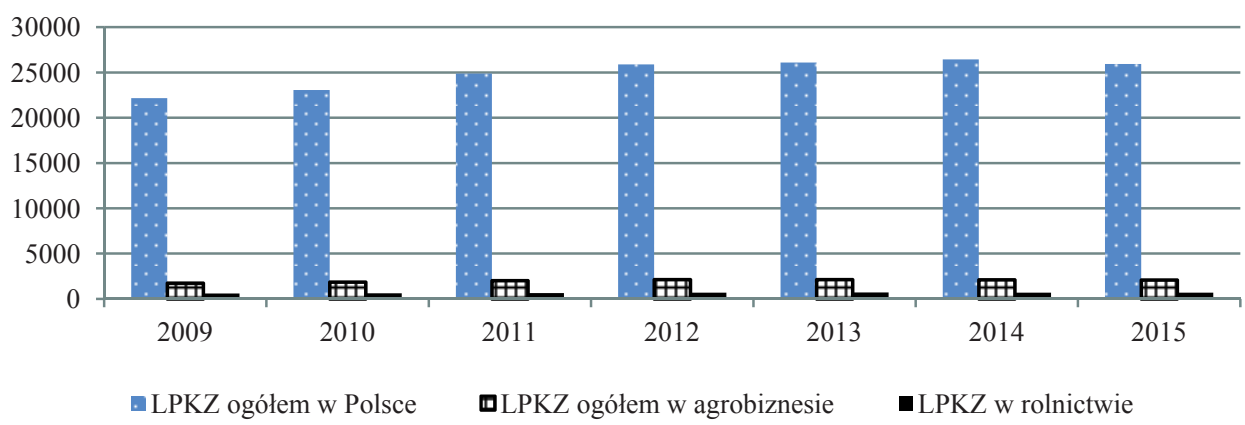

Rys. 1. Liczba podmiotów z kapitałem zagranicznym (LPKZ) w Polsce w latach 2009-2015

Fig. 1. Number of companies with foreign capital (LPKZ) in Poland in the years 2009-2015

Źródło: Opracowanie własne na podstawie danych GUS (2010-2016): Działalność gospodarcza podmiotów z kapitałem zagranicznym za poszczególne lata. Warszawa 2010-2016 oraz niepublikowanych danych GUS.

Kapitał zainwestowany w Polsce przez inwestorów zagranicznych w 2015 r. wynosił 222,5 mld zł. W analizowanym okresie wartość zainwestowanego kapitału zagranicznego dynamiczne zwiększała się (był o 17\% wyższy w 2015 r. w odniesieniu do 2009). W tych podmiotach ponad 90\% udziałów w kapitale podstawowym mają podmioty zagraniczne. Kapitał krajowy stanowił zaledwie 14,6\% w 2009 r. i zmniejszył się do 8,3\% w 2015 r. (Kacperska, 2018).

W analizowanym okresie liczba pracujących w podmiotach z kapitałem zagranicznym sukcesywnie zwiększała się. W latach 2009-2015 zatrudnienie w podmiotach z kapitałem zagranicznym wzrosło o $24,5 \%$ (tabela 1 ).

Tabela 1. Dynamika napływu podmiotów z kapitałem zagranicznym w Polsce, lata 2009-2015 (2009=100) (w \%)

Table 1. Dynamics of inflow of entities with foreign capital in Poland in the years 2009-2015 (2009=100) (in \%)

\begin{tabular}{l|ccccccc}
\hline \multicolumn{1}{c|}{ Wyszczególnienie } & 2009 & 2010 & 2011 & 2012 & 2013 & 2014 & 2015 \\
\hline Liczba podmiotów & 100 & 104,1 & 112,3 & 116,8 & 117,8 & 119,3 & 117,1 \\
Kapitał podstawowy & 100 & 105,0 & 107,9 & 115,1 & 116,3 & 119,9 & 123,7 \\
Kapitał zagraniczny & 100 & 103,7 & 107,2 & 116,8 & 122,6 & 127,5 & 132,8 \\
Liczba pracujących & 100 & 104,0 & 107,2 & 107,6 & 111,5 & 119,7 & 124,5 \\
\hline
\end{tabular}

Źródło: opracowanie własne na podstawie danych GUS (2001-2016) Działalność gospodarcza podmiotów z kapitałem zagranicznym za poszczególne lata. Warszawa 2010-2016.

Z analizy struktury branżowej napływu inwestycji zagranicznych do Polski wynika, że w analizowanym okresie ponad $70 \%$ podmiotów $\mathrm{z}$ kapitałem zagranicznym ulokowało swoją działalność w czerech branżach: 1) handlu i naprawie pojazdów, 2) przetwórstwie przemysłowym, 3) obsłudze rynku nieruchomości i 4) działalności profesjonalnej, naukowej i technicznej. W okresie tym inwestorzy zagraniczni lokowali też kapitał $\mathrm{w}$ rolnictwie i jego otoczeniu. Udział podmiotów z kapitałem zagranicznym działających w rolnictwie i przemyśle rolno-spożywczym stanowił średniorocznie około 8\% ogółu podmiotów z kapitałem zagranicznym działających w Polsce. 


\section{Liczba podmiotów z kapitałem zagranicznym działających w rolnictwie}

W latach 2009-2015 zaobserwowano wzrost zainwestowanego kapitału w rolnictwo, leśnictwo, łowiectwo i rybactwo. W 2009 r. zarejestrowano w Polsce w rolnictwie, przemyśle rolno-spożywczym i jego otoczeniu 1751 podmiotów z kapitałem zagranicznym. Do 2015 r. liczba podmiotów inwestujących w agrobiznesie zwiększyła się o 19 punktów procentowych do 2093 podmiotów i była o 2 punkty procentowe wyższa niż w samym rolnictwie. Dynamiczny wzrost liczby inwestujących podmiotów zaobserwowano w łowiectwie (wzrost o 100\%) uprawie roślin wieloletnich (wzrost o 58\%) i działalności usługowej wspomagającej rolnictwo następującej po zbiorach (wzrost o 42\%). Natomiast spadek liczby podmiotów zaobserwowano w działalności mieszanej (o 6,1\%) i w grupie chów i hodowla zwierząt (o 1,6\%). Podmioty zaliczane do sektora A stanowiły w 2009 r. $33,7 \%$ ogółu podmiotów z sektora agrobiznesu, i ich udział zwiększył się do 39,4\% (690 podmiotów) w $2015 \mathrm{r}$. W analizowanym okresie ponad 95\% podmiotów powstało w dziale 01 obejmującym rolnictwo poza leśnictwem i rybactwem (tabela 2).

Tabela 2. Struktura udziału podmiotów z kapitałem zagranicznym rolnictwie i agrobiznesie oraz dynamika ich napływu w latach 2009-2015

Table 2. Structure of the share of entities with foreign capital in agriculture and agribusiness and the dynamics of their inflow in 2009-2015

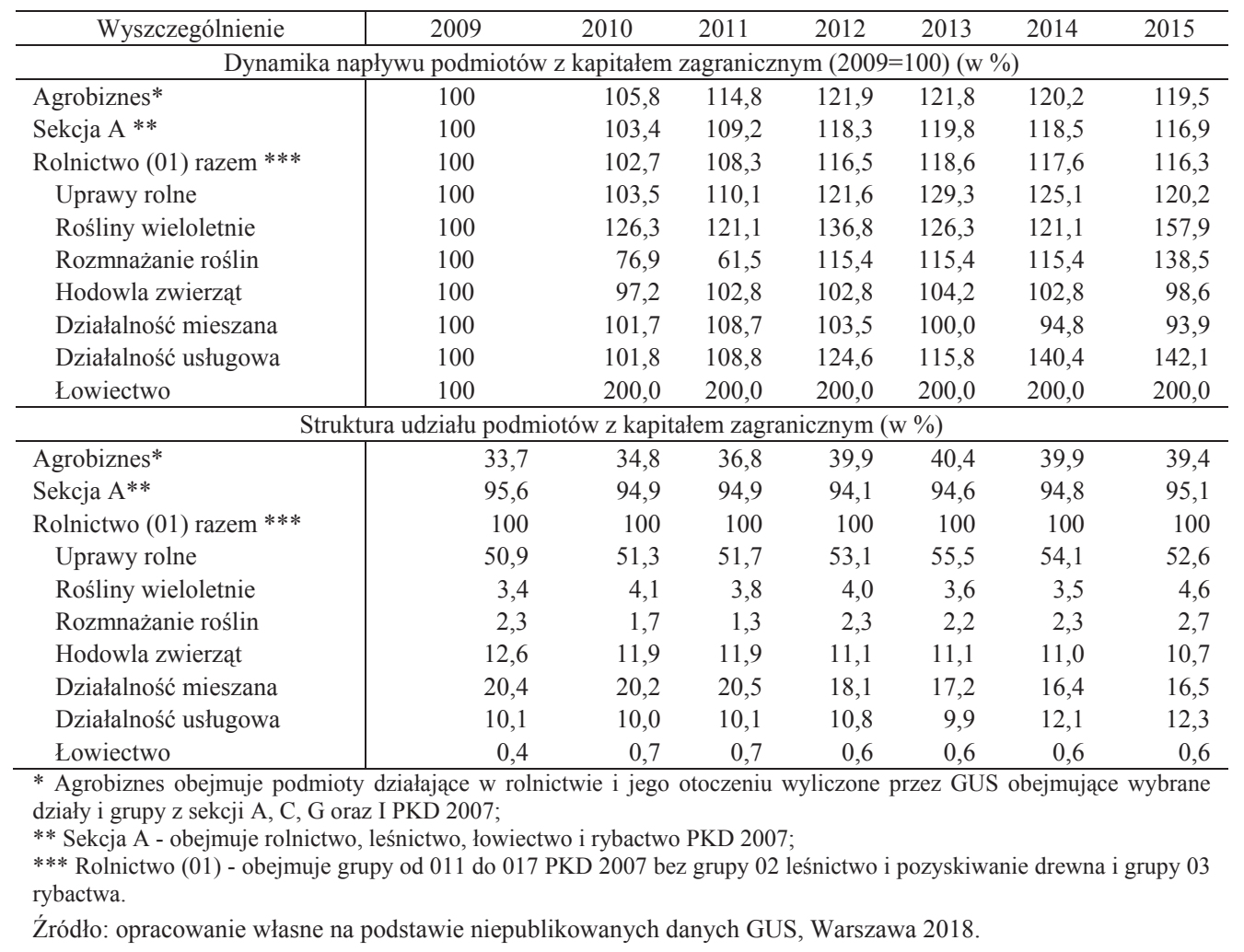


W strukturze napływu inwestorów zagranicznych dominujący udział wykazywały podmioty inwestujące w uprawy rolne (ponad $50 \%$ podmiotów z działu rolnictwo było w tej grupie). Na drugim miejscu była działalność mieszana - z tendencją spadkową z 20,4 \% udziału w 2009 r. do $16,5 \%$ w 2015 r. a na trzecim miejscu działalność usługowa z 12,3\% udziałem w 2015 r. (tabela 2).

W 2015 r. ponad połowa podmiotów z kapitałem zagranicznym z sektora agrobiznesu miała siedzibę zaledwie $w$ trzech województwach: mazowieckim - 24,2\%, zachodniopomorskim 16,4\% i wielkopolskim 11,1\%. W porównaniu z rokiem $2009 \mathrm{w} 11$ województwach odnotowano wzrost liczby podmiotów, największy w województwie podlaskim i podkarpackim. W pięciu województwach odnotowano spadki, największe w województwie warmińsko-mazurskim (o 21 pp.) i świętokrzyskim (o 6,7pp.). Jak wynika $\mathrm{z}$ rysunku 2 podmioty $\mathrm{z}$ kapitałem zagranicznym w agrobiznesie działały we wszystkich województwach, jednak przeważały w zachodniej części Polski. Podobna tendencja występowała w przypadku rozmieszczenia podmiotów z kapitałem zagranicznym w rolnictwie (rys. 3). W 2015 r. najwięcej podmiotów zarejestrowało działalność w województwie zachodniopomorskim - 37,8\%, lubelskim - 11\% i warmińsko-mazurskim - 9,1\%. Województwo zachodniopomorskie od 2009 r. wykazywało zdecydowaną przewagę liczebną nad pozostałymi województwami. W porównaniu z rokiem $2009 \mathrm{w} 11$ województwach odnotowano wzrost liczby podmiotów działających w rolnictwie, największy - trzykrotny w województwie mazowieckim i podlaskim. W pozostałych województwach odnotowano spadki inwestujących w rolnictwo, największe w opolskim $(26,7 \%)$ w lubuskim (o $24,3 \%$ ) i łódzkim (o $22,2 \%$ ).

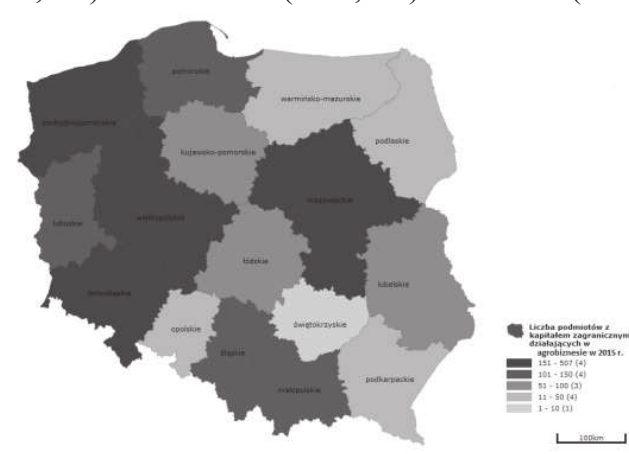

Rys. 2. Liczba podmiotów z kapitałem zagranicznym w agrobiznesie według województw w 2015 roku

Fig 2. Number of entities with foreign capital in agribusiness by voivodships in 2015

Źródło: jak w tabeli 2.

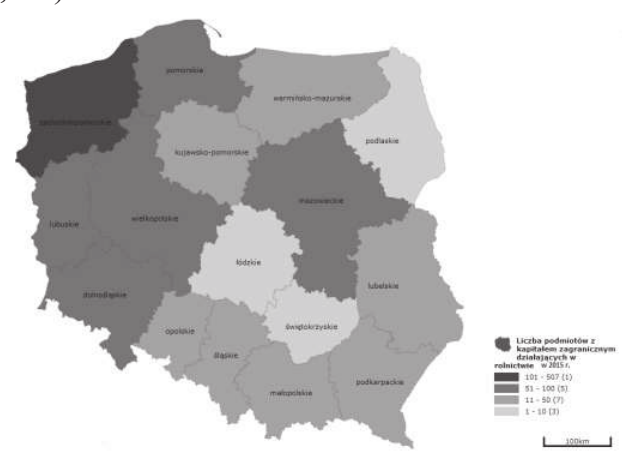

Rys. 3. Liczba podmiotów z kapitałem zagranicznym w rolnictwie według województw w 2015 roku

Fig. 3. Number of entities with foreign capital in agricultural by voivodships in 2015

Źródło: jak w tabeli 2. 


\section{Zatrudnienie w podmiotach z kapitałem zagranicznym działających w rolnictwie}

Do pracujących $\mathrm{w}$ podmiotach $\mathrm{z}$ kapitałem zagranicznym zalicza się osoby zatrudnione na podstawie stosunku pracy oraz pracodawców, właścicieli i współwłaścicieli oraz pracujących na własny rachunek zarówno w kraju jak i za granicą (GUS, 2016). Liczba pracujących $\mathrm{w}$ podmiotach $\mathrm{z}$ kapitałem zagranicznym działających $\mathrm{w}$ rolnictwie stanowiła w badanym okresie około $4 \%$ ogółu zatrudnionych w sektorze agrobiznesu. W końcu 2015 r. w podmiotach z udziałem kapitału zagranicznego w sektorze agrobiznesu pracowało 1373 tys. osób, zaś w rolnictwie 5,7 tys. osób. Liczba zatrudnionych w podmiotach z kapitałem zagranicznym z roku na rok zmniejszała się wykazując tendencję malejąca prawie dla wszystkich grup sekcji A. Liczba zatrudnionych w rolnictwie w analizowanym okresie uległa zmniejszeniu o 758 osób, czyli o 14,6 punktu procentowego. Wyjątek stanowiły działalność związana z chowem i hodowlą zwierząt, odnotowano tu wzrost zatrudnienia o $61 \%$ i działalność usługowa - wzrost zatrudnienia o $28 \%$ (tabela 3).

Najwięcej zatrudnionych było w grupie upraw rolnych - średniorocznie 40\%. W 2015 r. liczba zatrudnionych w tym dziale spadła o $25,7 \%$ w odniesieniu do roku 2014 . Na drugim miejscu pod względem liczby zatrudnionych był chów i hodowla zwierząt średniorocznie $25 \%$ a na trzecim działalność mieszana $\mathrm{z}$ średniorocznym udziałem wysokości 19,1\% (rys.4).

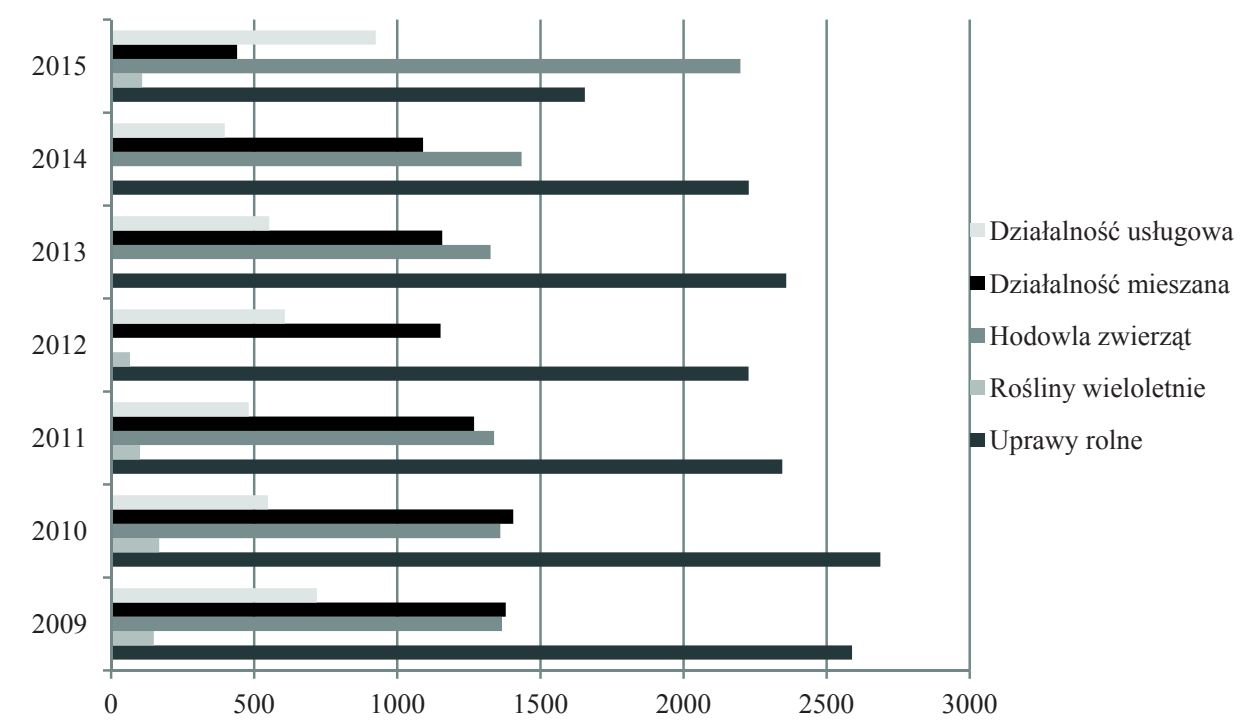

Rys. 4. Zatrudnienie w podmiotach z kapitałem zagraniczny poszczególnych grupach rolnictwa w latach 20092015

Fig. 4. Employment in entities with foreign capital in particular groups of agriculture in the years 2009-2015

Źródło: jak w tabeli 2.

Zatrudnienie w poszczególnych grupach działalności rolniczej przedstawia rysunek 2 . Wynika $\mathrm{z}$ niego, że $\mathrm{w}$ analizowanym okresie nastapiły duże zmiany w poszczególnych grupach. W latach 2009-2014 najwięcej zatrudnionych było przy uprawach rolnych, 
hodowli zwierząt i działalności mieszanej. Te trzy grupy w analizowanym okresie skupiały ponad $80 \%$ zatrudnionych w rolnictwie. Kolejną tendencja jest spadek zatrudnienia przy uprawach rolnych z 40\% w 2009 roku do $29,6 \%$ w 2015 roku. W 2015 roku nastapił wzrost zatrudnienia przy chowie i hodowli zwierząt o 53\% w odniesieniu do roku 2014 i o $61 \%$ w odniesieniu do 2009 roku (rys. 4).

W 2015 r. prawie 55\% ogółu osób pracujących w podmiotach z kapitałem zagranicznym $\mathrm{z}$ agrobiznesu pracowało $\mathrm{w}$ dwóch województwach: mazowieckim $(41,2 \%)$ i wielkopolskim (12,7\%) (rys. 5). W analizowanym przedziale czasowym w 11 województwach wzrosło zatrudnienie, najwięcej przybyło miejsc pracy w województwie podkarpackim - trzykrotny wzrost o 1194 osoby, pomorskim (o 88\%) i łódzkim (o 63\%). Natomiast największy spadek zatrudnionych był w województwie mazowieckim (spadek o prawie 7 tys. osób), kujawsko-pomorskim (832 osób) i (lubuskim o 225 osób).

W 2015 r. najwięcej zatrudnionych w podmiotach z kapitałem zagranicznym było w województwie zachodniopomorskim (35\%), wielkopolskim (17,1\%) i pomorskim (17\%). Łącznie $\mathrm{w}$ tych województwach skupione było prawie $70 \%$ ogółu pracujących $\mathrm{w}$ podmiotach zagranicznych $\mathrm{w}$ rolnictwie. W analizowanym okresie największa zmiana $\mathrm{w}$ zatrudnieniu była na terenie województwa mazowieckiego, gdzie nastapił prawie czterokrotny wzrost zatrudnienia. Odwrotna tendencja była w województwach: wielkopolskim, lubuski, lubelskim i dolnośląskim, gdzie zaobserwowano zmniejszanie się liczby zatrudnionych. Największy spadek był w województwie wielkopolskim o 624 osoby. Rysunek 6 przedstawia rozmieszczenie zatrudnienia $\mathrm{w}$ rolnictwie $\mathrm{w}$ podmiotach za kapitałem zagranicznym. Niestety ze względu na tajemnicę statystyczną dane dotyczące ośmiu województw nie zostały udostępnione przez GUS - kolor szary na rysunku 6.
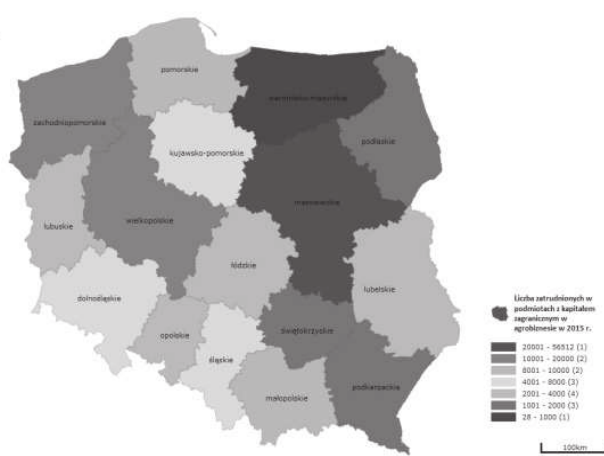

Rys. 5. Liczba zatrudnionych w podmiotach z kapitałem zagranicznym w agrobiznesie według województw w 2015 roku

Fig. 5. Number of employments with foreign capital in agribusiness by voivodships in 2015

Źródło: jak w tabeli 2.

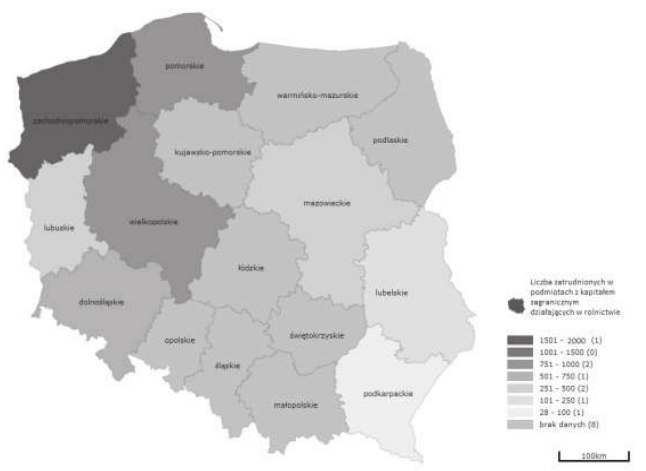

Rys. 6. Liczba zatrudnionych w podmiotach $\mathrm{z}$ kapitałem zagranicznym w rolnictwie według województw w 2015 roku

Fig. 6. Number of employments with foreign capital in agricultural by voivodships in 2015

Źródło: jak w tabeli 2. 


\section{Wartość i struktura kapitału w podmiotach z kapitałem zagranicznym w rolnictwie}

Do analizy struktury kapitału wykorzystano trzy kategorie ekonomiczne: kapitał własny, kapitał podstawowy i kapitał zagraniczny. Kapitał własny zgodnie z obowiązującymi przepisami prawa obejmuje kapitał podstawowy, kapitał zapasowy, kapitał $\mathrm{z}$ aktualizacji wyceny, pozostałe kapitały rezerwowe, niepodzielony wynik finansowy z lat ubiegłych, wyniki finansowy netto roku obrotowego oraz odpisy z zysku netto w ciagu roku obrotowego. Kapitał podstawowy w podmiotach gospodarczych zgodnie z definicja GUS oznacza rzeczywisty wkład właściciela lub współwłaściciela wniesiony na uruchomienie jednostki gospodarczej z chwila jej założenia, lub podniesiony później. Natomiast kapitał zagraniczny to kapitał wniesiony w postaci środków finansowych, rzeczowych aktywów trwałych oraz wartości niematerialnych i prawnych (GUS, 2016).

Wartość kapitału podstawowego podmiotów z udziałem zagranicznym działających w agrobiznesie wyniosła $14605,8 \mathrm{mln}$ zł i była o 7 pp. niższa w odniesieniu do roku poprzedniego oraz o $29,5 \% \mathrm{w}$ porównaniu do roku 2009. Odwrotną tendencję zaobserwowano wśród podmiotów z kapitałem zagranicznym inwestujących w rolnictwo. Wartość kapitału podstawowego w tym sektorze na koniec 2015 roku wyniosła 1272,8 mln zł i była o 43,2\% wyższa w porównaniu do 2009 roku. Udział wartości kapitału podstawowego podmiotów $\mathrm{z}$ sektora rolnictwa $\mathrm{W}$ odniesieniu do agrobiznesu średniorocznie był na poziomie $6,8 \%$ i charakteryzował się tendencją wzrostową (z 4,3 w 2009 do 8,7\% w 2015 roku. Wśród poszczególnych grup rolnictwa przez cały okres badawczy ponad 50\% kapitału było ulokowane w grupie upraw rolnych (tabela 3 ).

Tabela 3. Dynamika poszczególnych kategorii kapitału oraz dynamika zatrudnienia w podmiotach z kapitałem zagranicznym w sektorze rolno- spożywczym i w rolnictwie w latach 2009-2015 (2009=100)

Table 3. Dynamics of individual categories of capital and employment dynamics in entities with foreign capital in the agri-food sector and in agriculture in 2009-2015 (2009=100)

\begin{tabular}{l|rrrrrrr}
\hline \multicolumn{1}{c}{ Wyszczególnienie } & 2009 & 2010 & 2011 & 2012 & 2013 & 2014 & 2015 \\
\hline & \multicolumn{7}{c}{ Agrobiznes (w \%) } \\
Kapitał podstawowy & 100 & 97,0 & 70,7 & 74,3 & 71,2 & 76,2 & 71,5 \\
Kapitał zagraniczny & 100 & 96,6 & 69,1 & 72,8 & 69,8 & 74,7 & 70,7 \\
Kapitał własny* & 100 & 0,1 & 98,6 & 102,9 & 105,9 & 111,8 & 119,0 \\
Liczba pracujących & 100 & 101,6 & 85,4 & 98,8 & 97,7 & 102,7 & 99,3 \\
& & \multicolumn{7}{c}{ Rolnictwo (w \%) } & & \\
Kapitał podstawowy & 100 & 115,5 & 119,6 & 116,1 & 127,2 & 132,6 & 143,2 \\
Kapitał zagraniczny & 100 & 118,8 & 128,1 & 122,0 & 135,4 & 140,4 & 156,1 \\
Kapitał własny* & 100 & 0,3 & 110,3 & 124,7 & 145,1 & 134,6 & 157,0 \\
Liczba pracujących & 100 & 101,6 & 86,8 & 85,7 & 83,8 & 86,0 & 85,4 \\
\hline * dane dla podmiotów o liczbie pracujacych 10 i więcej osób.
\end{tabular}

* dane dla podmiotów o liczbie pracujących 10 i więcej osób.

Źródło: jak w tabeli 2.

W strukturze kapitału, kapitał zagraniczny inwestorów zagranicznych działających w agrobiznesie był dominujący. W analizowanym okresie jego udział wahał się od $93 \%$ do 95\%, co oznacza, że kapitał krajowy stanowił zaledwie 5-7\% - zależnie od roku. Udział kapitału zagranicznego wśród podmiotów z kapitałem zagranicznym $\mathrm{w}$ rolnictwie był 
niższy niż w agrobiznesie i wahał się od 85,2 w 2009 roku do $92,8 \%$ w 2015 roku. W analizowanym okresie o 56,1\% zwiększyła się wartość kapitału zagranicznego zainwestowanego w rolnictwie, która w 2015 roku osiagnęła 1181,4 mln zł. W poszczególnych grupach 01-07 rolnictwa zauważalny był wzrost udziału kapitału zagranicznego, szczególnie w uprawie roślin (zmiana udziału kapitału zagranicznego w odniesieniu do kapitału podstawowego z 75,7\% w 2009 roku do 98\% w 2015 roku) i chowie i hodowli zwierząt (zmiana z 71,8\% udziału w 2009 roku do 84,1 w 2015 roku) (tabela 3).

Kapitał własny przedsiębiorstw działających w agrobiznesie w latach 2009-2015 wykazywał się tendencją wzrastająca, jednak tempo wzrostu było niższe w odniesieniu do zmian w kapitale własnych w rolnictwie. W 2015 roku kapitał własny w sektorze rolnym zamknął się kwotą 2431,6 mln zł i był o 57\% wyższy niż w 2009 roku (tabela 3).

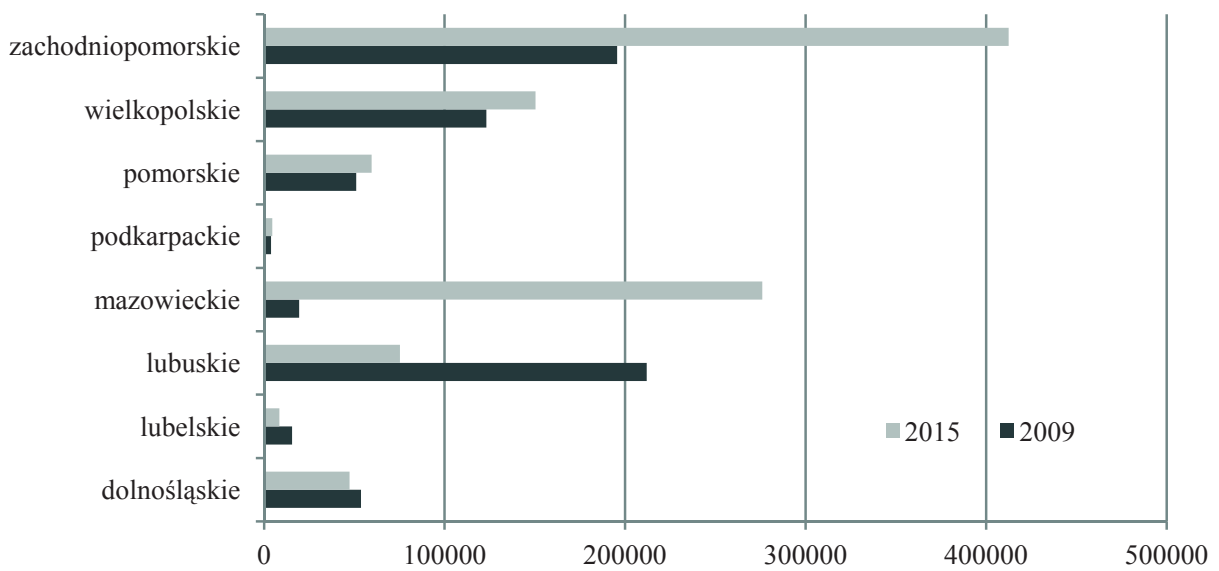

Rys. 7. Wartość kapitału zagranicznego w rolnictwie w ujęciu regionalnym w latach 2009-2015 (w tys. zł)

Fig. 7. Value of foreign capital by entities with foreign capital operating in agriculture on a regional basis in 20092015 (in PLN thousand)

Źródło: jak w tabeli 2.

Biorąc pod uwagę rozmieszczenie kapitału zagranicznego według województw, to w 2015 roku najwięcej kapitału było ulokowane w województwie zachodniopomorskim i mazowieckim i wielkopolskim (rys. 7).

\section{Handel zagraniczny podmiotów z kapitałem zagranicznym działających w rolnictwie}

Saldo obrotów handlu zagranicznego dokonywanych przez podmioty zagraniczne w rolnictwie poza 2011 i 2013 rokiem było dodatnie. Wartość eksportu osiagnięta przez podmioty z rolnictwa zamknęła się kwotą $959 \mathrm{mln}$ zł w $2015 \mathrm{r}$. Rok ten był wyjątkowo dobry dla sektora rolnego. Wartość importu w 2015 r. wyniosła 493,8 mld zł (rys. 8). 


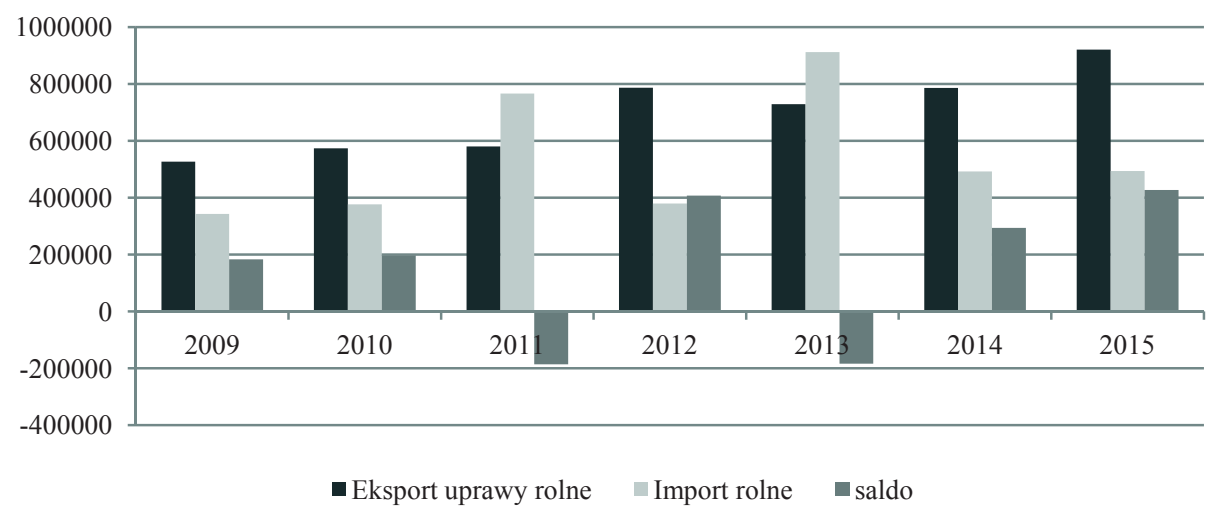

Rys. 8. Wartość handlu zagranicznego dokonywana przez podmioty z kapitałem zagranicznym działających w rolnictwie w latach 2009-2015 (w tys. zł)

Fig. 8. Value of foreign trade made by entities with foreign capital operating in agriculture in 2009-2015 (in PLN thousand)

Źródło: jak w tabeli 2.

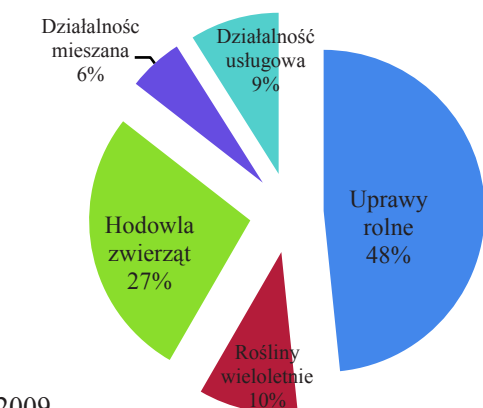

2009

Rys. 9. Struktura eksportu podmiotów z kapitałem zagranicznym działających w rolnictwie w 2009 r. $(\mathrm{w} \%)$

Fig. 9. The structure of exports of entities with foreign capital operating agriculture in 2009 (in \%) Źródło: jak w tabeli 2.

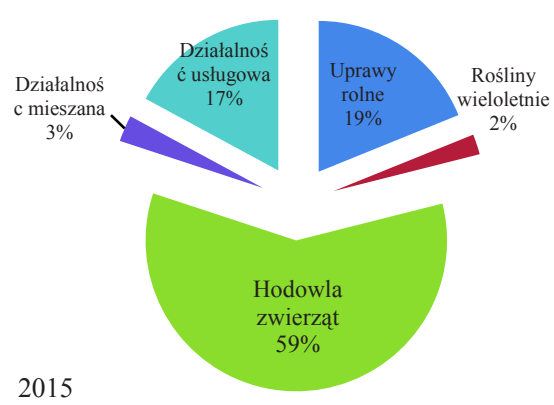

Rys. 10. Struktura eksportu podmiotów z kapitałem zagranicznym działających w rolnictwie w 2015 r. (w \%)

Fig. 10. The structure of exports of entities with foreign capital operating agriculture in 2015 (in \%)

Źródło: jak w tabeli 2.

Największy udział w eksporcie stanowiły uprawy rolne oraz chów i hodowla zwierząt. Ich łączny udział stanowił około 80\% wartości eksportu dla rolnictwa (rys. 9 i 10). W strukturze importu największy udział w analizowanym okresie wykazywały podmioty działające w hodowli zwierzą, w działalności usługowej i uprawie roślin. 


\section{Wyniki finansowe podmiotów z kapitałem zagranicznym w rolnictwie}

Wśród głównych elementów oceny przedsiębiorstw jak też całych sektorów sac podstawowe wyniki finansowe uzyskiwane przez podmioty gospodarcze. Do kategorii tej zaliczamy: (1) przychody z całokształtu działalności, określane jako przychody ogółem obejmujące przychody finansowe, przychody netto ze sprzedaży produktów, towarów i materiałów (ze sprzedaży w kraju i zagranica) oraz pozostałe przychody operacyjne; (2) koszty uzyskania przychodów, czyli koszty z całokształtu działalności określane jako koszty ogółem obejmujące koszty sprzedanych produktów, towarów i materiałów jak też pozostałe koszty operacyjne i finansowe; (3) wynik finansowy brutto; (4) wynik finansowy netto (5) oraz podstawowe wskaźniki rentowności (obrotu brutto, obrotu netto, kapitału aktywów) i poziomu kosztów (GUS, 2016).

Przychody ogółem uzyskiwane przez podmioty z kapitałem zagranicznym w rolnictwie charakteryzowały się tendencją wzrostową. Średniorocznie tempo wzrostu przychodów było na poziomie 14,8\%. W 2015 roku podmioty z udziałem kapitału zagranicznego uzyskały przychody z całokształtu działalności w wysokości 5990,2 mln zł, co oznaczało $43 \%$ wzrost w stosunku do spadkowego roku 2014 oraz dwukrotny wzrost w odniesieniu do 2009 roku (rys. 11). Wśród działów rolnictwa największe przychody generowały chów i hodowla zwierząt (53\% udziału w ogóle podmiotów z rolnictwa), uprawy rolne $25 \%$ oraz działalność usługowa - $12,6 \%$.

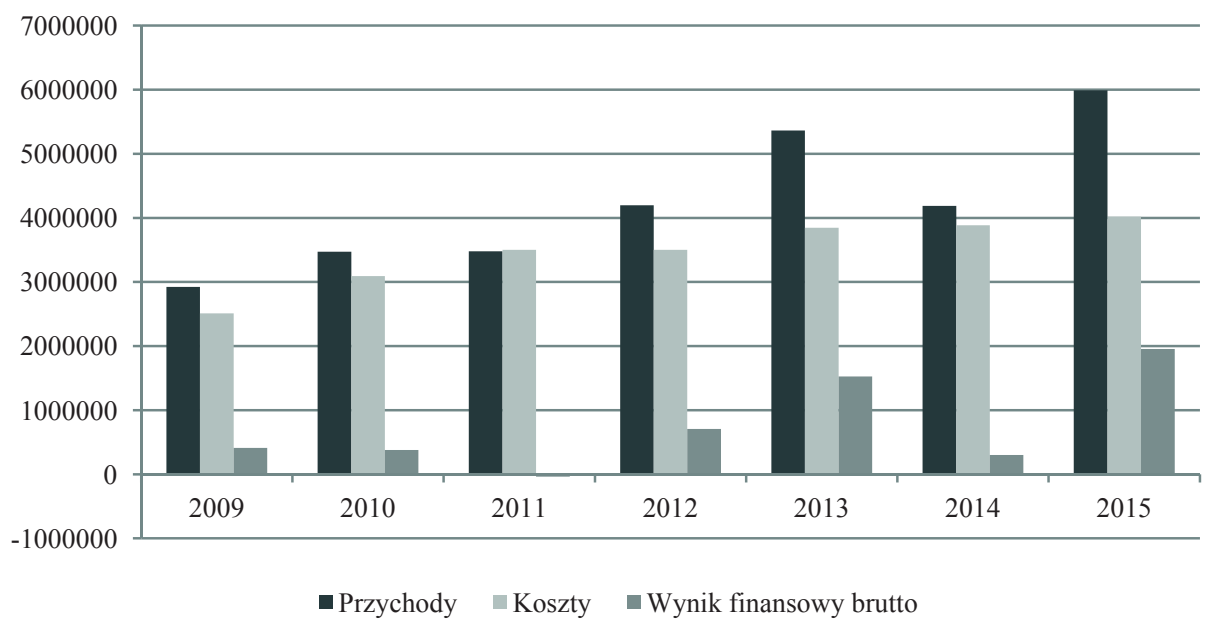

Rys. 11. Struktura podstawowych wyników finansowych podmiotów z kapitałem zagranicznym w rolnictwie w latach 2009-2015 (w tys. zl)

Fig. 11. Structure of basic financial results of entities with foreign capital in agriculture in 2009-2015 (in PLN thousand)

Źródło: opracowanie własne na podstawie niepublikowanych danych GUS, Warszawa 2018.

Koszty uzyskania przychodów z całokształtu działalności dla podmiotów zagranicznych działających w rolnictwie zamknęły się wartością 4019,3 mln zł w 2015 roku, co oznacza wzrost o 60\% w okresie 2009-2015. Z analizy dynamiki liczonej rok do 
roku wynika, że średniorocznie koszty wzrastały o 8,5 \% w rolnictwie i były o wyższe niż koszty w podmiotach działających w agrobiznesie.

Tabela 4. Wskaźniki ekonomiczne podmiotów z kapitałem zagranicznym działających w rolnictwie w latach 2009-2015

Table 4. Economic indicators of entities with foreign capital operating in agriculture in 2009-2015

\begin{tabular}{l|rrrrrrr}
\hline \multicolumn{1}{c|}{ Wyszczególnienie } & 2009 & 2010 & 2011 & 2012 & 2013 & 2014 & 2015 \\
\hline Wskaźnik rentowności obrotu brutto & 14,1 & 10,8 & $-0,8$ & 17,5 & 29,0 & 7,7 & 32,5 \\
Wskaźnik rentowności obrotu netto & 13,5 & 10,2 & $-1,4$ & 16,9 & 18,9 & 6,7 & 32,0 \\
Wskaźnik rentowności aktywów & 12,4 & - & $-1,3$ & 20,0 & 24,9 & 7,3 & 44,1 \\
Wskaźnik rentowności aktywów trwałych & 21,1 & - & $-2,3$ & 35,1 & 40,3 & 12,2 & 74,9 \\
Wskaźnik rentowności kapitału & 25,2 & - & $-2,7$ & 35,8 & 44,4 & 13,1 & 77,4 \\
\hline
\end{tabular}

Źródło: opracowanie własne na podstawie niepublikowanych danych GUS, Warszawa 20018.

Podmioty z kapitałem zagranicznym poza 2011 rokiem uzyskiwały zysk brutto z prowadzonej działalności. W 2011 roku straty z tytułu działalności gospodarczej wykazały podmioty z działalności mieszanej, co pociągnęło za sobą stratę w wysokości 209,3 mln zł. W większości rodzajów działalności podmiotów z poszczególnych grup rolnictwa wynik finansowy netto był dodatni. Działalność w rolnictwie okazała się rentownym przedsięwzięciem dla większości podmiotów z kapitałem zagranicznym. Jedynie w roku 2011 wskaźniki były ujemne (na co wskazywał wynik finansowy). Szczegółowe wyliczenia znajdują się w tabeli 4.

\section{Podsumowanie}

W latach 2009-2015 napływ inwestycji zagranicznych do polskiego rolnictwa charakteryzował się tendencja rosnącą $\mathrm{z}$ niewielkim spowolnieniem w ostatnim analizowanym roku. W analizowanym okresie inwestorzy zagraniczni byli zainteresowani polskim rolnictwem i jego otoczeniem. W 2015 r. w polskim rolnictwie działało 690 podmiotów z kapitałem zagranicznym, ponad połowa tych podmiotów ulokowana była w dziale uprawy rolne. Inwestorzy z sektora rolnego lokowali kapitał na terenie wszystkich województw, jednak ponad połowa podmiotów skupiona była w trzech województwach: mazowieckim, zachodniopomorskim i wielkopolskim.

Zatrudnienie w podmiotach z kapitałem zagranicznym w okresie 2009-2015 zmniejszyło się o $14,6 \%$ (780 osób). Największy spadek zatrudnienia zaobserwowano w dziale uprawy rolne i działalność mieszana. Tendencja wzrostowa była charakterystyczna dla działu chów i hodowla zwierząt, tu liczba pracujących zwiększyła się o 61\% (833 osoby).

W 2015 roku podmioty z kapitałem zagranicznym działające w rolnictwie dysponowały kapitałem (podstawowy) w wysokości 1258 mln zł. Wartość tego kapitału w analizowanym okresie wzrosła o 43,2\%. Kapitał zagraniczny zainwestowany sektorze rolnictwa zwiększył swoją wartość w analizowanym okresie o 56,1\%, wynosząc $1167 \mathrm{mln}$ zł w 2015 r. Ponad 94,2\% udziału kapitału podstawowego w podmiotach zagranicznych stanowił kapitał zagraniczny, oznacza to, że tylko 5,8\% udziału w tych podmiotach posiadało kapitał krajowy. 
Działalność inwestorów zagranicznych w rolnictwie okazała się opłacalna. Uzyskiwane wyniki finansowe brutto i netto wykazywały zysk prawie w całym analizowanym okresie (straty wykazano tylko w 2011 r.).

\section{Literatura}

Chechelski, P. (2008). Wpływ procesów globalizacji na polski przemysł spożywczy (The impact of globalization processes on the Polish food industry). IERiGŻ, Warszawa seria Studia i Monografie nr 145.

Geldner, M. (1986). Przyczynek do teorii zagranicznych inwestycji zagranicznych (A contribution to the theory of foreign foreign investment). Monografie i opracowania, SGPiS, Warszawa, nr 193.

Gorynia, M. (2005). (red.) Strategie firm polskich wobec ekspansji inwestorów zagranicznych (Strategies of Polish companies regarding the expansion of foreign investors). $P W E$, Warszawa.

GUS (2011). Działalność gospodarcza podmiotów z kapitałem zagranicznym w 2010 r. (Economic activity of entities with foreign capital in 2010). Informacje i opracowania statystyczne. Warszawa.

GUS (2012). Działalność gospodarcza podmiotów z kapitałem zagranicznym w 2011 r. (Economic activity of entities with foreign capital in 2011). Informacje i opracowania statystyczne. Warszawa.

GUS (2013). Działalność gospodarcza podmiotów z kapitałem zagranicznym w 2012 r. (Economic activity of entities with foreign capital in 2012). Informacje i opracowania statystyczne. Warszawa.

GUS (2014). Działalność gospodarcza podmiotów z kapitałem zagranicznym w 2013 r. (Economic activity of entities with foreign capital in 2013). Informacje i opracowania statystyczne. Warszawa.

GUS (2015). Działalność gospodarcza podmiotów z kapitałem zagranicznym w 2014 r. (Economic activity of entities with foreign capital in 2014). Informacje i opracowania statystyczne. Warszawa.

GUS (2016). Działalność gospodarcza podmiotów z kapitałem zagranicznym w 2015 r. (Economic activity of entities with foreign capital in 2015). Informacje $i$ opracowania statystyczne. Warszawa.

Jodkowski, A. (1995). Zagraniczne inwestycje bezpośrednie w Polsce jako element kształtowania konkurencyjności (Foreign direct investment in Poland as element of shaping competitiveness). Raporty, Warszawa $\mathrm{Nr} 36$

Kacperska, E.M. (2000). Rola bezpośrednich inwestycji zagranicznych w rozwoju przedsiębiorczości w sektorze rolno-spożywczym w Polsce (The role of foreign direct investments in the development of entrepreneurship in the agriculture-food sector in Poland). Maszynopis pracy doktorskiej. SGGW Warszawa.

Kacperska, E.M. (2016). Foreign Direct Investment in World Economy. Problems of World Agriculture, 16(1), 155-168.

Kacperska E.M. (2018). Rozmieszczenie regionalne bezpośrednich inwestycji zagranicznych w Polsce (Regiona distribution of foreign direct investments in Poland). Zeszyty Naukowe WSES w Ostrolece 4(31), $202-222$.

Kraciuk, J. (2004). Rola korporacji transnarodowych we współczesnej gospodarce światowej (The role of transnational corporations in the modern world economy). W: Egzemplifikacja międzynarodowych stosunków gospodarczych, pod redakcją P. Bożyka. WSHiP, Warszawa, 76-98.

NBP (2018). Zagraniczne inwestycje bezpośrednie w Polsce i polskie inwestycje bezpośrednie za granicą w 2016 roku (Foreign direct investments in Poland and Polish direct investments abroad in 2016). Warszawa.

UNCTAD (2005). World Investment Report 2005, Transnational Corporations and the Internationalization of R\&D New York and Geneva, http://unctad.org/en/Docs/wir2005overview_en.pdf

Zorska, A. (2002). (red.). Korporacje międzynarodowe w Polsce. Wyzwania a dobie globalizacji i regionalizacji (International corporations in Poland. Challenges and the age of globalization and regionalization). Difin, Warszawa.

Do cytowania / For citation:

Kacperska E.M. (2018). Działalność podmiotów z kapitałem zagranicznym w polskim rolnictwie. Problemy Rolnictwa Światowego, 18(4), 222-235; DOI: 10.22630/PRS.2018.18.4.113

Kacperska E.M. (2018). Economic Activity of Entities with Foreign Capital in Polish Agriculture (in Polish). Problems of World Agriculture, 18(4), 222-235; DOI: 10.22630/PRS.2018.18.4.113 